\title{
Phylogenetic analysis of black queen cell virus and deformed wing virus in honeybee colonies infected by mites in Van, Eastern Turkey1)
}

\author{
ZEYNEP KARAPINAR, BEKIR OĞUZ*, ENDER DINÇER ${ }^{* *}$, CIHAT ÖZTÜRK*** \\ Faculty of Veterinary Medicine, Department of Virology, Balikesir University, 10100 Balıkesir, Turkey \\ *Department of Parasitology, ${ }^{* *}$ Department of Virology, Faculty of Veterinary Medicine, \\ Yuzuncu Yil University, 65080 Van, Turkey \\ **Advanced Technology Education, Research and Application Center, Mersin University, 33343, Mersin, Turkey
}

Karapınar Z., Oğuz B., Dinçer E., Öztürk C.

Phylogenetic analysis of black queen cell virus and deformed wing virus in honeybee colonies infected by mites in Van, Eastern Turkey

Summary

This study aimed to determine the presence and prevalence of viral and parasitic infections causing high rates of colony loss in honey bee colonies in Van province, eastern Turkey. Twenty-six different apiaries were collected from five counties in Van province. These samples were tested by Reverse-Transcriptase PCR (RT-PCR) for acute bee paralysis virus (ABPV), chronic bee paralysis virus (CBPV), black queen cell virus (BQCV) and deformed wing virus (DWV). Selected positives were sequenced, phylogenetically analyzed and investigated in terms of Varroa. DWV and BQCV were identified in $69.23 \%(18 / 26)$ and $88.46 \%(23 / 26)$ of the bees respectively whereas ABPV and CBPV were not detected in the sampled apiaries. Results of the phylogenetic analysis of DWV and BQCV sequences showed 94-100\% similarity to DWV and BQCV isolates obtained from Genbank. Prevalence of varroasis was $89 \%$ (23/26) in Van. The obtained samples were identified as Varroa destructor by morphological investigation. The study showed that viral and parasitic agents commonly infect honeybees in Van province, with high prevalence rates for BQCV and DWV. There was also a high degree of conservation of DWV and BQCV sequences distinct from DWV and BQCV isolates from other geographical regions. These findings, including current prevalence and phylogenetic analysis data for DWV, BQCV and varroazis in honeybees, are useful for future studies.

Keywords: PCR, honey bee, DWV, BQCV, varroasis

Apiculture contributes significantly to the agricultural economy and vegetative production through worldwide pollination (32). As in other countries, beekeeping has become a developing industry in Turkey (10). Turkey is an important region for beekeeping in terms of its surface area, topographic character, climate and vegetation. Recent studies have reported that bee viruses play a role in the collapse of bee colonies. It has also been reported that the probability of the simultaneous infection of bee colonies in which collapses are observed with viral and parasitic pathogens is higher than the probability of the other pathogens being observed together $(4,7,33)$.

Bee viruses first described in the early $20^{\text {th }}$ century have become one of the biggest threats to the health

1) This work was supported financially by a grant from Yuzuncu Yil University Scientific Research Projects (YYUBAP/2015-HIZ-VF223). of honeybees. These include Deformed Wing Virus (DWV), Black Queen Cell Virus (BQCV), Acute Bee Paralysis Virus (ABPV) and Chronic Bee Paralysis Virus (CBPV) (17).

DWV is an RNA virus with a single fibril and virus positive polarity, located in the genus Iflavirus (15). The virus, which is can be seen in different seasons, infects both larvae and adults, causing wrinkles in wings, shrinking of the body, faded color, shortened lifespan and regression in eggs in queens and adults $(3,9,17)$. In addition to horizontal and vertical infection, it has also been determined that the agent infects through Varroa destructor $(28,29)$.

BQCV of the genus Cripavirus of the family Dicistroviridae has an RNA genome with an active single strand (6). It causes thickening in the cell walls of larvae and pupa, death of queen bee larvae, diarrhea 
in adult bees, intestinal edema and expanded abdomen infections that progress latently (17). The disease increases in the spring and summer, spreading both in horizontal and vertical ways. The disease agent is detected in eggs, which shows that the disease is also transmitted transovarially (11). The infection is carried by the parasite Nosema apis while Varroa destructor also plays a role $(7,29)$.

CBPV is an RNA virus with a single fibril with active positive polarity. Paralysis, shaking and crawling are seen in affected bees, and the colony may collapse suddenly (23). The agent is transmitted both horizontally and vertically, with a significant number of agents in feces (24).

ABPV of the genus Cripavirus of the family Dicistroviridae, has an RNA genome with an active single fibril (13). Following a 3 to 5 day incubation, affected bees suffer shaking in the wings and body, paralysis and sudden death while colony collapses are also observed (17). Varroa destructor plays a role as both vector activator (29). As well as horizontal and vertical infection, detection of the agent in sperm shows that the disease may also be transmitted genitally (34).

Varroa species (mite: Varroidae) was first collected from the eyes of Apis cerena larvae in 1904 by E. Jacobson in Java (Indonesia), and named Varroa jacobsoni. In 2000, from their evaluation of the sequence and body measurement differences among Varroa mites, Anderson and Trueman determined that Varroa destructor is a distinct species (1). They also divided this species into two classes, Japan-Thailand and Korea haplotype, based on reproductivity. Varroa mites are important vectors in the transmission of viral diseases (12). More specifically, $V$. destructor may infect honey bees at all developmental stages: larvae, pupa and adult. Apis mellifera has devastating destructive effects on bee colonies (1).

This study had the aim of determining the prevalence of viral and parasitic infection in honey bee colonies in Van province in eastern Turkey, using PCR, and to determine the molecular characterization of honey bee viruses in this region.

\section{Material and methods}

Samples. A total of 260 adult worker bees were collected from 26 colonies at five apiaries located in counties within Van province between April and June 2015. The locations of the sampled regions are shown in Figure 1. The bee colonies provided from the fieldwork samples were determined to be distant from each other and dead bee samples were provided at specified times, determined with the colony owners during the study. At least ten adult worker bees from each colony were collected. The main clinical feature in all colonies was the presence of signs of diarrhea and bee death.

RNA extraction and cDNA synthesis. The ten bees collected from the same beehive were considered as one single sample and placed in a sterile tube before removing heads and wings and homogenizing abdomens and thoraxes

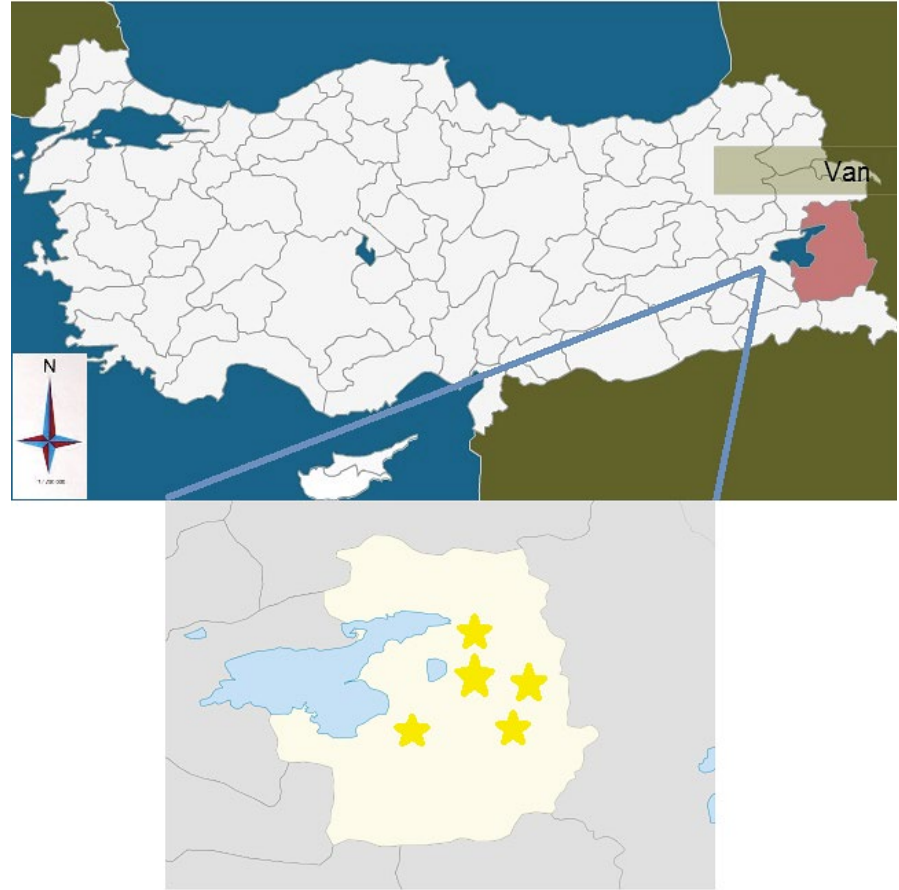

Fig. 1. Distribution of beekeping regions sampled in Van

in a $10 \mathrm{~mL}$ phosphate buffer solution (phosphate-buffered saline-PBS) at $+4^{\circ} \mathrm{C}$. The homogenate was used in the supernatant viral RNA extraction that was formed after centrifugation for 15 minutes at $4500 \mathrm{rpm}$. RNA extraction was conducted in accordance with the kit procedures using viral nucleic acid isolation kit (Thermo Scientific GeneJET Viral DNA and RNA Purification Kit).

The cDNA synthesis of each sample was made in accordance with the kit procedures (Thermo Scientific RevertAid First Strand K1622, USA). The first mixture was prepared with $3 \mu \mathrm{L}$ sterile distilled water, $0.5 \mu \mathrm{L}$ random hexamer primer and $3 \mu \mathrm{L} \mathrm{RNA}$, and the tubes were placed in a thermocycler. After having been kept in this device at $70^{\circ} \mathrm{C}$ for 5 minutes the tubes were placed in ice. Next, the second mixture was prepared with $2.0 \mu \mathrm{L} 5 \times$ reaction buffer, $1.0 \mu \mathrm{L}$ $10 \mathrm{mM}$ dNTP mix and $0.5 \mu \mathrm{L}$ M-MuLV reverse transcriptase at $3.5 \mu \mathrm{L}$. This was added to the tubes containing the first mixture, which were then incubated at $48^{\circ} \mathrm{C}$ for 45 minutes. The series of primers used in the RT-PCR reaction, and the PCR size and references are given in Table $1(6,14,25)$.

Reverse transcription-polymerase chain reaction (RT-PCR). For PCR amplification, $30 \mu 1$ PCR master mix was formed with $3 \mu \mathrm{l}$ of DNA, $75 \mathrm{mM}$ Tris- $\mathrm{HCl}(\mathrm{pH} 8.8)$, $20 \mathrm{mM} \mathrm{NH}_{4}\left(\mathrm{SO}_{4}\right)_{2}, 1.5 \mathrm{mM}$ of $\mathrm{MgCl}_{2}$, primers $10 \mathrm{pmol}$,

Tab. 1. Primers used for DWV, CBPV, ABPV, BQCV detection

\begin{tabular}{|c|c|c|c|}
\hline Primer & Sequence (5'-3') & Length (bp) & Reference \\
\hline DWV1 & TTTGCAAGATGCTGTATGTGG & \multirow[t]{2}{*}{395} & \multirow{2}{*}{$\begin{array}{l}\text { Gülmez } \\
\text { et al. (2009) }\end{array}$} \\
\hline DWV2 & GTCGTGCAGCTCGA-TAGGAT & & \\
\hline CBPV1 & GTTGTCATGGTTAACAGGATACGAG & \multirow[t]{2}{*}{455} & \multirow{2}{*}{$\begin{array}{l}\text { Ribiere } \\
\text { et al. (2002) }\end{array}$} \\
\hline CBPV2 & TCTAATCTTAGCACGAAAGCCGAG & & \\
\hline ABPV1 & TTATGTGTCCAGAGACTGTATCCA & \multirow[t]{2}{*}{900} & \multirow{2}{*}{$\begin{array}{l}\text { Benjeddou } \\
\text { et al. (2001) }\end{array}$} \\
\hline ABPV2 & GCTCCTATTGCTCGGTTTTTCGGT & & \\
\hline BQCV1 & TGGTCAGCTCССАСТАССТTAАAC & \multirow[t]{2}{*}{700} & \multirow{2}{*}{$\begin{array}{l}\text { Benjeddou } \\
\text { et al. (2001) }\end{array}$} \\
\hline Bacv2 & GCAACAAGAAGAAACGTAAACCAC & & \\
\hline
\end{tabular}




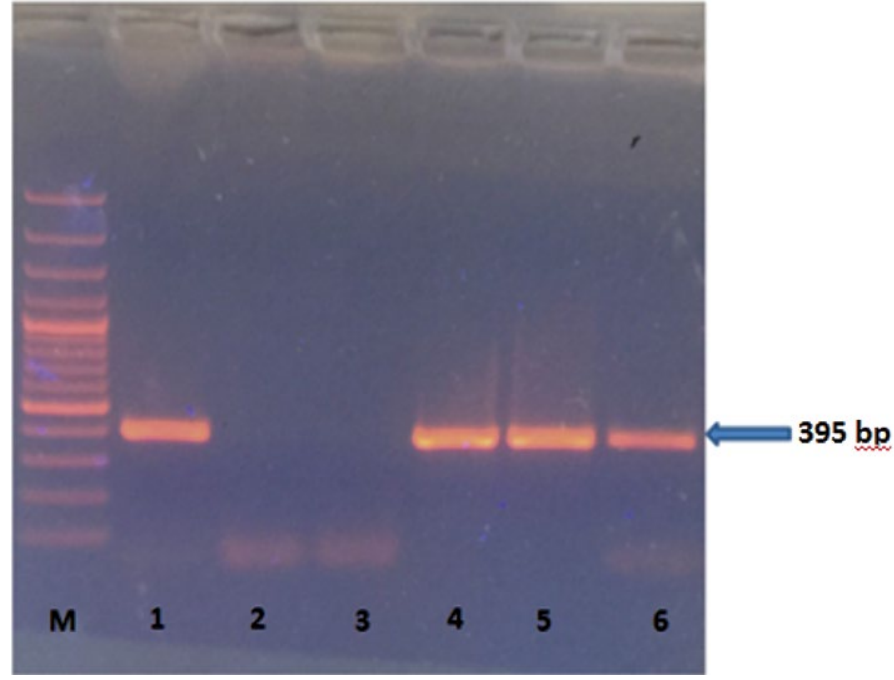

Fig. 2. Ethidium bromide stained agarose gel electrophoresis image of the RT-PCR products of DWV

Explanations: M - Marker (100 bp DNA ladder); 1, 4, 5, 6 - positive samples

$0.2 \mathrm{mM}$ of dNTP and Taq DNA polymerase at $0.5 \mathrm{U}$ (MBI, Fermentas, Lithuania). The temperature programs used in the thermocycler varied with virus type as follows:

For DWV, following denaturation at $95^{\circ} \mathrm{C}$ for 6 minutes, the values were 60 seconds at $54^{\circ} \mathrm{C}, 30$ seconds at $72^{\circ} \mathrm{C}$ and 30 seconds at $95^{\circ} \mathrm{C}$. This temperature program was repeated for 35 cycles. The process was completed with a final extension of 7 minutes at $68^{\circ} \mathrm{C}$.

For $\mathrm{BQCV}, \mathrm{ABPV}$, and $\mathrm{CBPV}$, following denudation for 2 minutes at $95^{\circ} \mathrm{C}$, the values were 60 seconds at $55^{\circ} \mathrm{C} ; 120$ seconds at $68^{\circ} \mathrm{C}$ and 30 seconds at $95^{\circ} \mathrm{C}$. This temperature program was repeated for 40 cycles. The process was completed with a final extension of 7 minutes at $68^{\circ} \mathrm{C}$.

For evaluation purposes, standard $100 \mathrm{bp}$ was used, and the amplified DNA products were stained with ethidium bromide in $1 \%$ agarose gel before examination under UV light in a Gel Imaging Device (Fig. 2 and 3).

Sequencing and phylogenetic analyses. Before the analyses, five sample series selected from among the positive products were purified using a commercial purification kit (High Pure PCR Cleanup Micro Kit, Roche, Germany) and exposed to capillary electrophoretic separation in a private laboratory (Refgen, Ankara, Turkey). The series analyses were conducted on the products with the help of Bioedit Version (7.0.5.3.), while the phylogenetic map was formed using Mega 6.1 (27). The phylogenetic tree included those sequences selected from the different countries aligned with the Turkish sequences.

V. destructor determination. A certain number of broods were collected from each hive and their eyes were opened while the adult bees brought to the laboratory were analyzed for Varroa. Sedimentation was used to separate the Varroa mites from the wastes of the hive wood floor. One part of waste was mixed with 10 parts of oil. Varroa mites that accumulated on the surface of the oil were collected after the waste had precipitated. In adult bees, the level of the membrane and wings between the pled regions

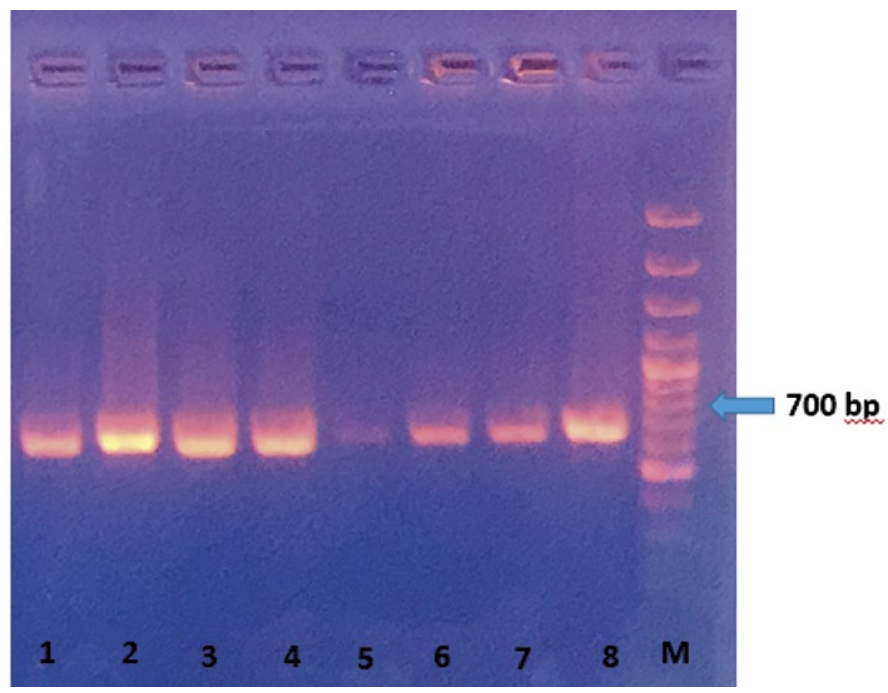

Fig. 3. Ethidium bromide stained agarose gel electrophoresis image of the RT-PCR products of $B Q C V$

Explanations: $\mathrm{M}$ - Marker (100 bp DNA ladder); 1-8 - positive samples

segments was examined in the area where the chitin layer was thin and soft. In order to gain a clear result, the bees were placed in jars of warm water at $10^{\circ} \mathrm{C}$ and one drop of detergent was dropped on them. The bees were then examined for Varroa approximately 10 minutes after being removed from the jars.

\section{Results and discussion}

One of the important problems for the apiculture sector is bee pests. Although apiculture has a very important place for Turkey's economy, studies conducted in this field are rare. To keep honey bee pests under control, it is particularly essential that viral infections are diagnosed quickly and accurately (11).

One study that investigated bee viruses in the Black Sea region reported CBPV in 25\% (7/28) of bees and BQCV in $21.42 \%(6 / 28)$ whereas ABPV was not detected (22). BQCV positivity rates determined by PCR ranged between 22.2 and $100 \%$ in samples obtained from different regions (19). In our study, BQCV prevalence was $88.46 \%(23 / 26)$, which has attracted attention since it is a higher prevalence rate than that in previous studies. Given that companies in Van deal with migratory beekeeping and travel to cities with warmer climates, like Mersin and Hatay,

Tab. 2. DWV, CBPV, ABPV, BQCV positivity rates according to the sam-

\begin{tabular}{|l|c|c|c|c|c|}
\hline \multicolumn{1}{|c|}{$\begin{array}{c}\text { Sampled } \\
\text { region }\end{array}$} & $\begin{array}{c}\text { Number } \\
\text { of hives } \\
\text { examined }\end{array}$ & DWV & BQCV & ABPV & CBPV \\
\hline Erek & 5 & $4(80 \%)$ & $5(100 \%)$ & $0(0 \%)$ & $0(0 \%)$ \\
Kasımoğlu & 10 & $7(70 \%)$ & $9(90 \%)$ & $0(0 \%)$ & $0(0 \%)$ \\
\hline Özalp Yolu & 3 & $3(100 \%)$ & $3(100 \%)$ & $0(0 \%)$ & $0(0 \%)$ \\
Bostaniçi & 5 & $1(20 \%)$ & $4(80 \%)$ & $0(0 \%)$ & $0(0 \%)$ \\
Kale Yolu & 3 & $3(100 \%)$ & $2(66.66 \%)$ & $0(0 \%)$ & $0(0 \%)$ \\
Total & 26 & $18(69.23 \%)$ & $23(88.46 \%)$ & - & - \\
\hline
\end{tabular}


during winter, and considering the existence of the virus in the Black Sea region, it is possible to conclude that BQCV is highly prevalent in Turkey. Similarly, the virus has been detected in $86 \%$ of adult samples and $23 \%$ of pupae in a survey of healthy French bee colonies (29) and recently in Austrian apiaries (7).

Like our study, DWV was reported by various studies of samples collected from Ordu in 2007 and Hatay in 2009 (14, 20). Phylogenetic analysis data from different geographical areas also indicate that DWV is widely distributed in Apis mellifera honey bees in Europe (31). A study of 40 bee colonies in Algeria in 2013 reported a DWV positivity rate of $40 \%$ (16).

Our study showed that DWV and BQCV positivity rates are fairly high in Van. While 18 of a total of 26 hives $(69.23 \%)$ were positive for DWV, $23(88.46 \%)$ were positive for BQCV (Tab. 2). Thus, similarly to previous research, we found that BQCV and DWV are the two most common honey bee pathogens (35).

In our study, structural polyproteins gene-region specific primers of PCR procedures were performed for nucleic acid amplification for BQCV and DWV. These two viruses were selected from positive samples from each region for series analyses in order to create a phylogenetic map (Fig. 4 and 5).

The Turkish DWV strains obtained in the present study were highly similar among themselves and with a previous Turkish isolate (FJ011106). The identity rate was $100 \%$. The comparative sequence analysis determined that the DWV sequences (KU521779, KU521780, KU521781 and KU521782) showed 98-100\% identity with European DWV isolates from Denmark, England and Italy. The similarity rates were $100 \%, 98-100 \%$ and $99 \%$, respectively. They also showed high identity with South American isolates from Chile and Brazil, as well as Asian isolates from Vietnam, with similarity rates

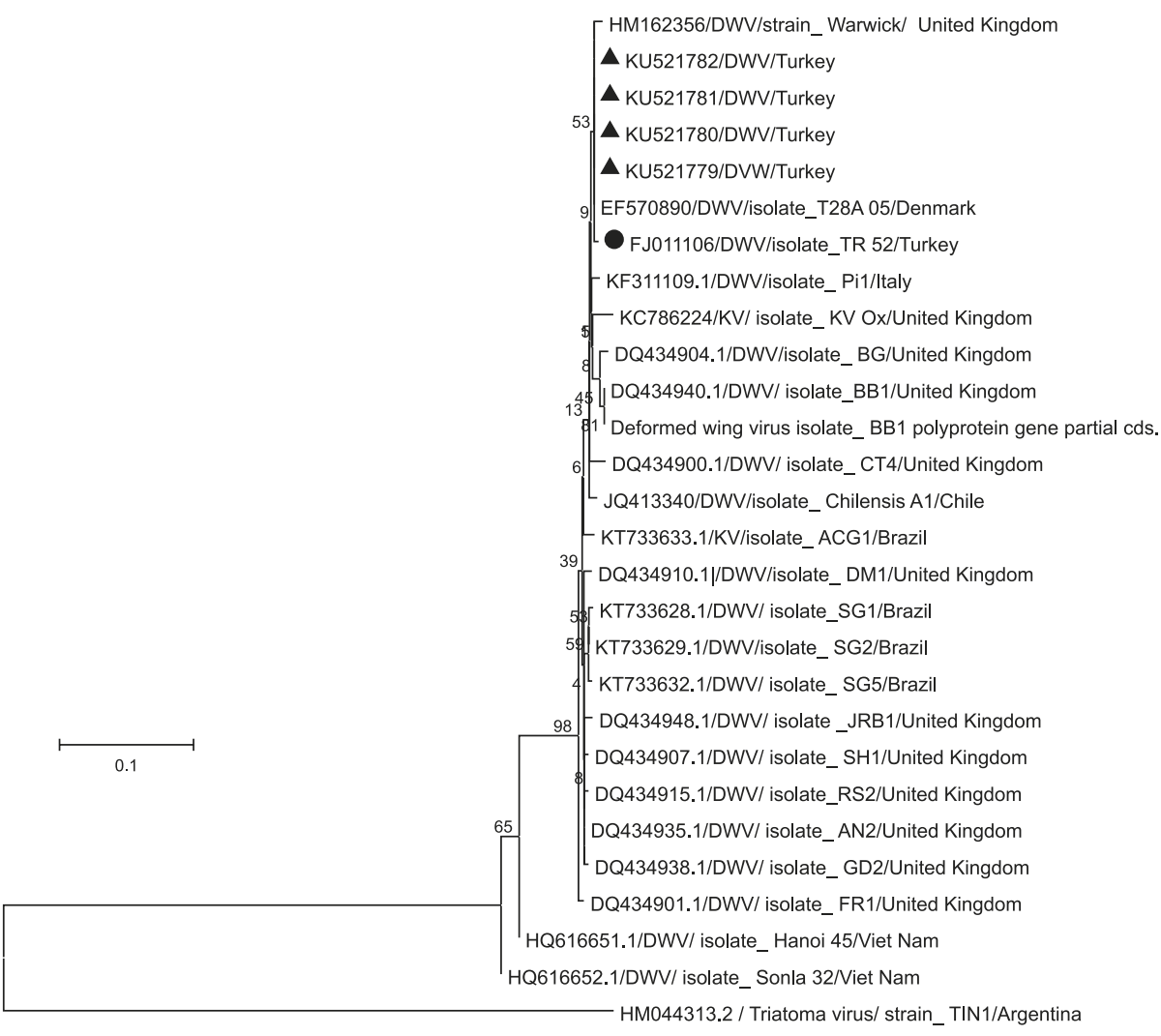

Fig. 4. Neighbor-joining analysis of polyprotein gene of DWV. New sequences from Van province are indicated with "filled triangle", Turkish isolate "filled circle" and other sequences are indicated by the Accession Number, isolate name and country respectively. Triatoma virus is included as outgroup

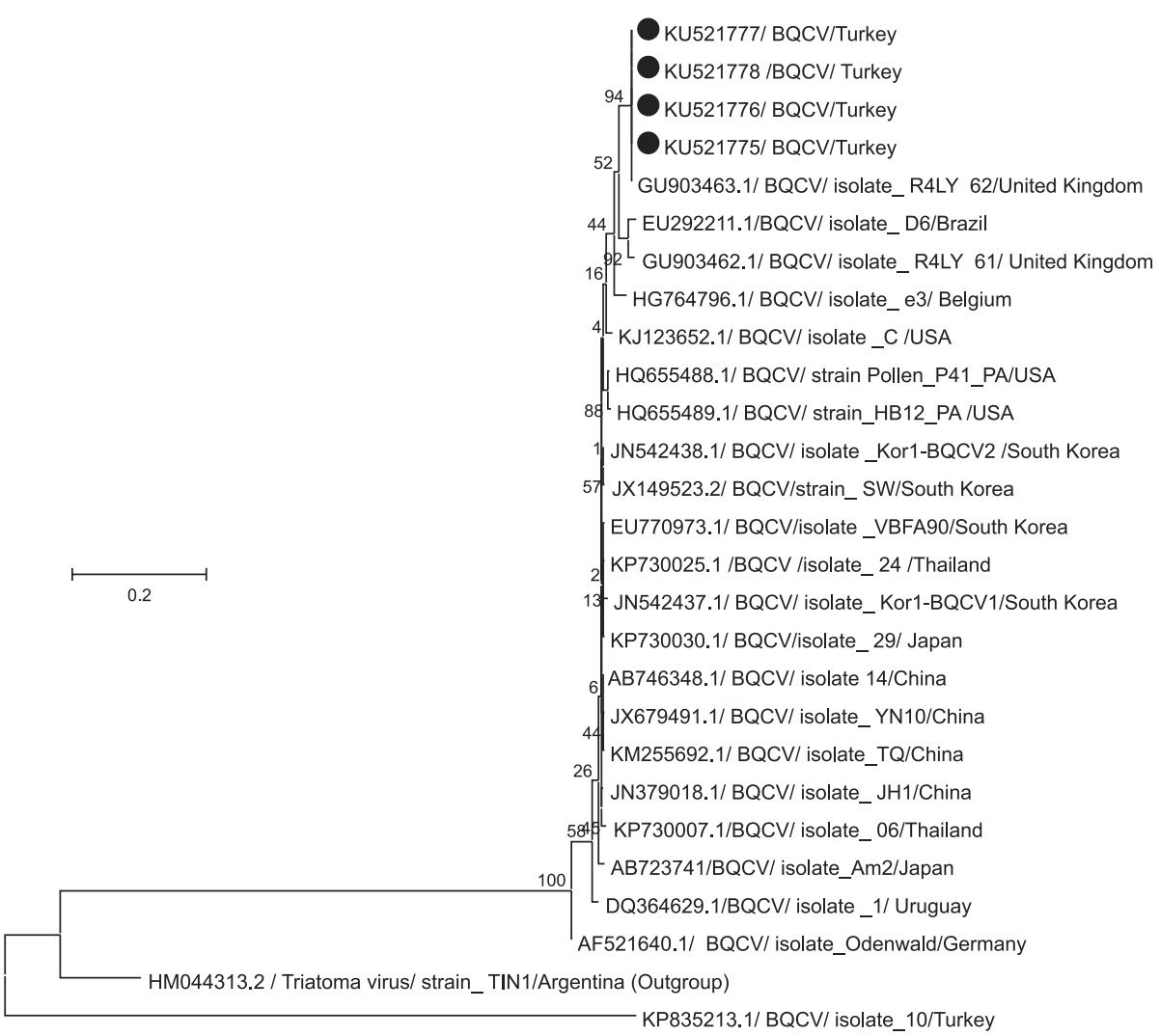

Fig. 5. Neighbor-joining analysis of capsid gene of BQCV. New sequences from Van province are indicated with "filled circle" and other sequences are indicated by the Accession Number, isolate name and country respectively. Triatoma virus is included as an outgroup 
Tab. 3. Number of hives examined and varroasis infestation rate

\begin{tabular}{|l|c|c|}
\hline \multicolumn{1}{|c|}{ Region } & Number of hives examined & Infestation rate \\
\hline Erek & 5 & 100 \\
\hline Kasımoğlu & 10 & 80 \\
\hline Özalp Yolu & 3 & 67 \\
\hline Bostaniçi & 5 & 100 \\
\hline Kale Yolu & 3 & 100 \\
\hline
\end{tabular}

of $99 \%, 98 \%$ and $94 \%$ respectively. There was also a high degree of conservation of nucleotide sequences between isolates from different geographical regions worldwide, as reported in previous studies $(5,8)$.

The phylogenetic tree for the Turkish BQCV isolates was created and compared with BQCV isolates from different countries, using the Triatoma virus strain from Argentina as an outgroup. The BQCV sequences (KU521775, KU521776, KU521777 and KU521778) showed $100 \%$ homology among themselves. The comparative sequence analysis determined that the Turkish BQCV sequences were highly similar to European isolates from Belgium and England, with similarity rates of $95 \%$ and $95-100 \%$ respectively. They also showed identity with Asian isolates from South Korea, China, Japan and Thailand at 94-95\%, 95\%, $95 \%$ and $95 \%$, respectively. They showed $94 \%$ identity with the North America isolate and 95\% and 96\% identity with South American isolates from Uruguay and Brazil, respectively. Parallel to a previous study, the present study found that all BQCV sequences were very closely related to each other and distinct from the Triatoma virus (18).

We observed Varroasis in 23 (89\%) of the 26 bee colonies of the five apiculture companies examined in Van. The average size of the sampled Varroa mites was $1.2 \mathrm{~mm}$ while the width was $1.6 \mathrm{~mm}$. The number of beehives examined and the results are shown in Table 3.

From the morphological and genetic examinations of the Varroa mites collected from various cities and regions of Turkey it was determined that $V$. destructor had the Korean genotype (30). V. destructor was detected by morphological examination of the mites obtained in the present study.

Various studies have reported that $V$. destructor is very common across various regions of Turkey (2, 26 ), having been detected at a rate of $25 \%$ in Elaziğ region and $27 \%$ in the Southern Marmara region. It is currently accepted that $V$. destructor is found in all regions of Turkey at different rates and that no regions are free of it $(21,26)$. Varroasis rates were $100 \%$ in the beehives examined in Van, Central Anatolia and Erzurum. Likewise, Varroasis rates were $100 \%$ in beehives examined in Hakkari in southeastern Turkey (2) while $V$. destructor was found in $100 \%$ of 900 colonies sampled from 30 different companies in six different wintering areas in Hatay in southern Turkey (21). The present study followed these findings, with Varroasis detected in 23 of 26 bee colonies examined, indicating an infection rate for Van region of $89 \%$. Parallel with previous research, this indicates that the disease has continued to spread in the region.

Recent studies have reported that the probability of simultaneous infection of bee colonies in which collapses are observed with viral and parasitic pathogens is higher than the probability of the other pathogens being observed together. Parallel to these results, the present study found that viral and parasitic agents infect honey bees at similar rates. BQCV and DWV were highly prevalent in Van province. The molecular characterization data showed a high degree of conservation of DWV and BQCV sequences within the sampled region that are also distinct from DWV and BQCV isolates from different geographical regions worldwide. We believe that this study provides useful findings for future studies by including molecular characterization data supported by prevalence data for DWV, BQCV and Varroasis in honey bees in one region of Turkey.

\section{References}

1. Anderson D. L., Trueman J. W. H.: Varroa jacobsoni (Acari: Varroidae) is more than one species. Exp. Appl. Acarol. 2000, 24, 165-189.

2. Aydın A.: Hakkari Yöresinde Varroasis'in Yaygınlığı. YYU Vet. Fak. Derg. 2012, 23, 129-130.

3. Bailey L., Ball B. V.: Honey Bee Pathology. Academic Press, London 1991.

4. Bakonyi T., Farkas R., Szendroi A., Dobos-Kovacs M., Rusvai M.: Detection of acute bee paralysis virus by RT-PCR in honey bee and Varroa destructor field samples: rapid screening of representative Hungarian apiaries. Apidologie 2002, 33, 63-74

5. Barriga G. P., Cifuentes Munoz N., Rivera P. A., Gutierrez M., Shmaryahu A., Valenzuela P. D. T., Engel E. A.: First detection and complete genome sequence of deformed wing virus in Chilean honeybees. Virus Genes 2012, 45, 606-609.

6. Benjeddou M., Leat N., Allsopp M., Davison S.: Detection of acute bee paralysis virus and black queen cell virus from honey bees by reverse transcriptase PCR Appl. Environ. Microbiol. 2001, 67, 2384-2387.

7. Berényi O., Bakonyi T., Derakhshifar I., Köglberger H., Nowotny N.: Occurrence of six honey bee viruses in diseased Austrian apiaries. Appl. Environ. Microbiol. 2006, 72, 2414-2420.

8. Berényi O., Bakonyi T., Derakhshifar I., Köglberger H., Topolska G., Ritter W., Pechhacker H., Nowotny N.: Phylogenetic Analysis of Deformed Wing Virus Genotypes from Diverse Geographic Origins Indicates Recent Global Distribution of the Virus. Appl. Environ. Microbiol. 2007, 73, 3605-3611.

9. Bowen-Walker P. L., Martin S. J., Gunn A.: The transmission of deformed wing virus between honeybees (Apis mellifera L.) by the ectoparasitic mite Varroa jacobsoni Oud. J. Invertebrate. Pathol. 1999, 73, 101-106.

10. Buyuk M., Tunca I. R., Taskın A.: The studies on presence of Nosema spp. in Turkey. Turkjans 2014, 1, 234-238.

11. Chen Y. P., Pettis J. S., Collins A., Feldlaufer F.: Prevalence and transmission of honey bee viruses. Appl. Environ. Microbiol. 2006, 72, 606-611.

12. Francis R. M., Nielsen S. L., Kryger P.: Varroa-Virus Interaction in Collapsing Honey Bee Colonies. Plos One 2013, 8, e 57540.

13. Govan A., Leat N., Allsopp M., Davison S.: Analysis of the Complete Genome Sequence of Acute Bee Paralysis Virus Shows That it Belongs to the Novel Group of insect-infecting RNA Viruses. Virol. 2000, 277, 457-463.

14. Gülmez Y., Bursalı A., Tekin Ş.: First molecular detection and characterization of deformed wing virus (DWV) in honeybees (Apis mellifera L.) and mite (Varroa destructor) in Turkey. Afr. J. Biotechnol. 2009, 8, 3698-3702.

15. Lanzi G., De Miranda J. R., Boniotti M. B., Cameron C. E., Lavazza A., Capucci L., Camazine S. M., Rossi C.: Molecular and biological characterization of deformed wing virus of honey bees (Apis mellifera L). J. Virol. 2006, 80, 4998-5009.

16.Loucif-Ayad W., Chefrour A., Algharibeh M., Haddad N.: First detection of deformed wing virus of honeybees in Algeria. Phytoparasitica 2013, 41, 445-447. 
17. Maramorosch K., Shatkin A.: Honey Bee Viruses, [in:] F. A. Murphy (ed.) Advances in Virus Research. Academic Press, Salt Lake CityUT, 2007, p. 33-80

18. Mookhploy W., Kimura K., Disayathanoowat T., Yoshiyama M., Hondo K., Chantawannakul P.: Capsid Gene Divergence of Black Queen Cell Virus Isolates in Thailand and Japan Honey Bee Species. J. Econ. Entomol. 2015, 1-5; DOI: $10.1093 /$ jee/tov102.

19. Muz D., Muz M. N.: A molecular epidemiological study of black queen cell virüs in honeybees (Apis mellifera) of Turkey: the first genetic characterization and phylogenetic analysis of field viruses. Apidologie 2017, DOI: 10.1007/ s13592-017-0531-5.

20. Muz M. N., Muz D.: Survey of the occurrence of Deformed Wing Virus and multiple parasites of queens (Apis mellifera L.) in apiaries with collapsed colonies in Hatay, Turkey. J. Apic. Res. 2009, 48, 204-208.

21. Muz M. N., Solmaz H., Yaman M., Karakavuk M.: Kıs Salkımı Erken Bozulan Arı Kolonilerinde Paraziter ve Bakteriyel Patojenler. YYU Vet. Fak. Derg. 2012, 23, 147-150.

22. Okur Gümüşova S., Albayrak H., Kurt M., Yazıcı Z.: Prevalence of three honey bee viruses in Turkey. Vet. Arhiv. 2010, 80, 779-785.

23. Olivier V., Blanchard P., Chaouch S., Lallemand P., Schurr F., Celle O. Dubois E., Tordo N., Thieéy R., Houlgatte R., Ribière M.: Molecular characterization and phylogenetic analysis of chronic bee paralysis virus, a honey bee virus. Virus Res. 2008, 132, 59-68.

24. Ribière M., Lallemand P., Iscache A. L., Schurr F., Celle O., Blanchard P., Olivier V., Faucon J. P.: Spread of Infectious Chronic Bee Paralysis Virus by Honeybee (Apis mellifera L) Feces. Appl. Environ. Microbiol. 2007, 73, 7711-7716.

25. Ribiere M., Triboulot C., Mathieu L., Aurieres C., Faucon J. P., Pepin M. Molecular diagnosis of chronic bee paralysis virus infection. Apidologie 2002, 33, 339-351

26. Simşek H.: Elazığ Yöresi Bal Arılarında Bazı Parazit ve Mantar Hastalıklarının Araştırılması. Ank. Üniv. Vet. Fak. Derg. 2005, 52, 123-126.
27. Tamura K., Stecher G., Peterson D., Filipski A., Kumar S.: MEGA6: Molecular Evolutionary Genetics Analysis version 6.0. Mol. Biol. Evol. 2013, 30, 2725-2729.

28. Tentcheva D., Gauthier L., Jouve S., Canabady-Rochelle L., Dainat B., Cousserants F., Colin M. E., Bail B. V., Bergoin M.: Polymerase chain reaction detection of deformed wing virus (DWV) in Apis mellifera and Varroa destructor. Apidologie 2004a, 35, 431-439.

29. Tentcheva D., Gauthier L., Zappulla N., Dainat B., Cousserans F., Colin M. E. Bergoin M.: Prevalence and seasonal variations of six bee viruses in Apis mellifera L and Varroa destructor mite populations in France. Appl. Environ. Microbiol. 2004b, 70, 7185-7191.

30. Warrit N., Hagen T. A. R., Smith D. R., Çakmak I.: A survey of Varroa destructor strains on Apis mellifera in Turkey. J. Apicult. Res. 2004, 43, 190-191.

31. Wilfert L., Long G., Leggett H. C., Schmid-Hempel P., Butlin R., Martin S. J. M., Boots $M$. : Deformed wing virus is a recent global epidemic in honeybees driven by Varroa mites. Science 2016, 351, 594-598.

32. Yang B., Peng G., Li T., Kadowaki T.: Molecular and phylogenetic characterization of honey bee viruses, Nosema microsporidia, protozoan parasites, and parasitic mites in China. Ecol. Evol. 2013, 3, 298-311.

33. Yue C., Genersch E.: RT-PCR analysis of deformed wing virus in honeybees (Apis mellifera) and mites (Varroa destructor). J. Gen. Virol. 2005, 86, 3419$-3424$

34. Yue C., Schröder M., Bienefeld K., Genersch E.: Detection of viral sequences in semen of honeybees (Apis mallifera): Evidence for vertical transmission of viruses through drones. J. Invertebr. Pathol. 2006, 2, 105-108.

35. Zhang X., He S. Y., Evans J. D., Pettis J. S., Yin G. F., Chen Y. P.: New evidence that deformed wing virus and black queen cell virüs are multi-host pathogens. J. Invertebr. Pathol. 2012, 109, 156-159.

Corresponding author: Asistant Professor Dr. Zeynep Karapınar, Faculty of Veterinary Medicine, Department of Virology, Balikesir University, 10100 Balıkesir, Turkey; e-mail: zeynepkarapinar@gmail.com 